\title{
Dual Effects of D-Amphetamine on Dopamine Neurons Mediated by Dopamine and Nondopamine Receptors
}

\author{
Wei-Xing Shi, Chen-Lun Pun, Xue-Xiang Zhang, Michelle D. Jones, and Benjamin S. Bunney \\ Department of Psychiatry, Yale University School of Medicine, New Haven, Connecticut 06510
}

By increasing dopamine (DA) release and activating feedback mechanisms, amphetamine and related psychostimulants are known to inhibit DA cell firing. Here, we report that D-amphetamine also has an excitatory effect on DA cells, which under control conditions, is masked by the inhibitory effect of D-amphetamine and is revealed when D2-like receptors are blocked. Thus, using in vivo single-unit recording in rats, we found that the selective D2 antagonist raclopride not only blocked the inhibition induced by D-amphetamine but also enabled D-amphetamine to excite DA cells. The excitation, expressed as an increase in both firing rate and bursting, persisted when both D1- and D2-like receptors were blocked by $\mathrm{SCH} 23390$ and eticlopride, suggesting that it is not mediated by DA receptors. The norepinephrine uptake blocker nisoxetine mimicked the effect of D-amphetamine, especially the increase in bursting, whereas the 5-HT uptake blocker fluoxetine produced no significant effect. Adrenergic $\alpha 1$ antagonists prazosin and WB4101 and the nonselective $\alpha$ antagonist phenoxybenzamine completely blocked increase in bursting induced by $D$-amphetamine and partially blocked the increase in firing rate. The $\alpha 2$ antagonist idazoxan and the $\beta$ antagonist propranolole, however, failed to prevent $\mathrm{D}$-amphetamine from producing the excitation. Thus, revising the traditional concept, this study suggests that $D$-amphetamine has two effects on DA cells, a DA-mediated inhibition and a non-DA-mediated excitation. The latter is mediated in part through adrenergic $\alpha 1$ receptors.

Key words: amphetamine; drug abuse; addiction; psychostimulant; dopamine; norepinephrine; prazosin; adrenergic; $\alpha 1$; substantia nigra; ventral tegmental area; burst; single-unit recording
Amphetamine and related psychostimulants, including cocaine, are known to block dopamine (DA) re-uptake and to increase DA release. Because of activation of DA autoreceptors and long-loop feedback pathways from DA-innervated areas, these drugs also inhibit DA cell firing (Bunney et al., 1973; Einhorn et al., 1988; Shi et al., 2000). This DA-mediated feedback inhibition has been shown to be altered after chronic treatment with amphetamine or cocaine and has been suggested to play an important role in the development of behaviors associated with the abuse of these drugs (White and Wang, 1984; Wolf et al., 1993; Gao et al., 1998; Henry et al., 1998; Lee et al., 1999).

In the course of characterizing D-amphetamine-induced inhibition of DA neurons, we found that the selective D2 antagonist raclopride, injected after $\mathrm{D}$-amphetamine, not only reversed the inhibition induced by D-amphetamine but further increased the activity of the cell to above baseline. Initially, this increase was thought to be a "rebound" phenomenon of the cell or to be attributable to blockade of a tonic DA inhibition induced by spontaneous DA release. When analyzing burst activity, we noticed that the level of bursting of the cell was increased several fold after raclopride. This large increase led us to suspect that mechanisms other than the two proposed above may be involved. In this report, we present evidence suggesting that D-amphetamine has, in addition to its well known inhibitory effect, an excitatory

Received Dec. 21, 1999; revised Feb. 23, 2000; accepted Feb. 23, 2000.

This work was supported in part by United States Public Health Service Grants MH52686 (W.-X.S), DA12944 (W.-X.S), and MH28849 (B.S.B), and the State of Connecticut.

Correspondence should be addressed to Dr. Wei-Xing Shi, Department of Psychiatry, Yale University School of Medicine, 333 Cedar Street, SHM B-272, P.O. Box 208066, New Haven, CT 06520. E-mail address: wei-xing.shi@yale.edu.

Copyright (C) 2000 Society for Neuroscience $0270-6474 / 00 / 203504-08 \$ 15.00 / 0$ effect on DA cells. Under control conditions, this excitatory effect is masked by the inhibitory effect of D-amphetamine. Raclopride, by blocking the inhibitory effect, reveals the excitatory effect of D-amphetamine.

Parts of this work have been published previously in abstract form (Shi et al., 1997a, 1998, 1999; Zhang et al., 1999).

\section{MATERIALS AND METHODS}

Single-unit recordings in vivo. All procedures were performed in accordance with those outlined in the Guide for the Care and Use of Animals U.S. Government Principles, with Public Health Service Policy and the Animal Welfare Act, and approved by the Yale Animal Care and Use Committee. Male Sprague Dawley rats weighing between 250 and $400 \mathrm{gm}$ were used. Most experiments were performed in chloral hydrateanesthetized rats $(400 \mathrm{mg} / \mathrm{kg}$, i.p., with supplemental doses administered via a lateral tail vein). A few experiments were performed in nonanesthetized rats (low cerveau isolé preparations), which were prepared as described previously (Shi et al., 1997b). Briefly, rats were initially anesthetized with halothane (Halocarbon Laboratory, River Edge, NJ). All pressure points and incision sites were infiltrated with the long-acting, local anesthetic lidocaine hydrochloride, and the brain stem was transected using a blunt, flattened syringe needle. Halothane anesthesia was discontinued for at least $30 \mathrm{~min}$ before beginning experiments. Throughout the experiment, body temperature was maintained at 36$38^{\circ} \mathrm{C}$ with a heating pad.

DA cells in the substantia nigra (SN) and ventral tegmental area (VTA) were identified and recorded extracellularly as described previously (Bunney et al., 1973; Grace and Bunney, 1980, 1983). Glass microelectrodes were made using a Narishige (Tokyo, Japan) electrode puller, filled with $0.5 \mathrm{M} \mathrm{NaCl}$, and had an impedance between 5 and $15 \mathrm{M} \Omega$. The electrode was lowered through a small burr hole drilled above the SN and the VTA (3.0 mm anterior to the lamboidal suture and $0.5-2.5 \mathrm{~mm}$ lateral to the midline) using a hydraulic microdrive. DA cells were normally found between 6.5 and $8.5 \mathrm{~mm}$ below the cortical surface. Interspike intervals (ISI) and firing rates were collected on-line via an interface (Lab-PC ${ }^{+}$; National Instrument, Austin, Taxes) to a personal computer 
A



B

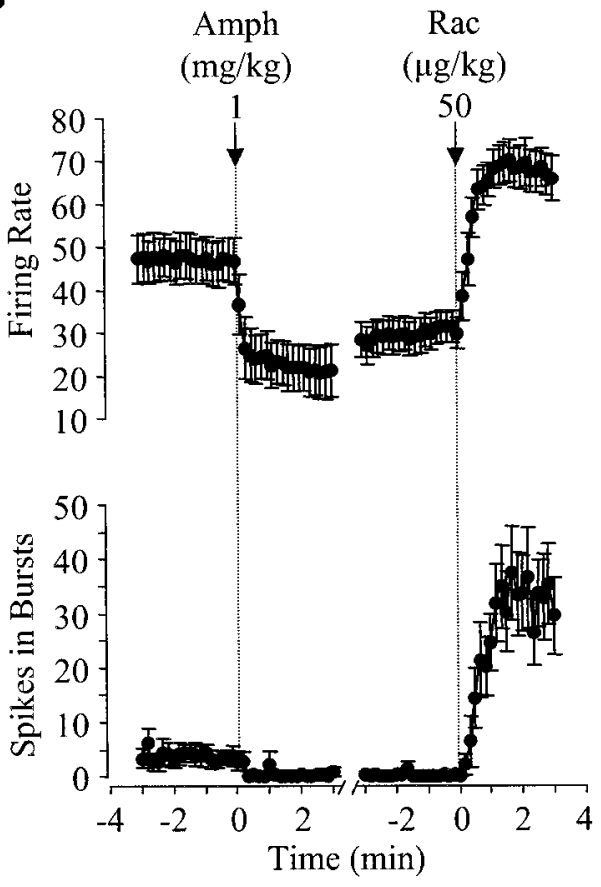

Figure 1. Excitation of DA neurons after raclopride reversal of D-amphetamineinduced inhibition. $A$, Representative recordings from a nigral DA neuron showing that raclopride $(R a c)$ not only reversed the inhibition induced by D-amphetamine $(A m p h)$ but further increased the activity of the cell to above baseline. Four different parameters were measured: firing rate (spikes/10 sec), number of spikes in bursts (spikes/10 sec), number of bursts (bursts/10 $\mathrm{sec}$ ), and ISI variation coefficient (percent of mean ISI/10 sec). Of the four measurements, the number of spikes in bursts was increased most significantly. $B$, Summary of data from eight cells tested with D-amphetamine followed by raclopride. After raclopride, both firing rate and the number of spikes in bursts were significantly increased compared with predrug baseline $\left(F_{(18,268)}=26.914, p<\right.$ 0.0005 ; and $F_{(18,268)} \stackrel{1}{=} 17.434, p<0.0005$, respectively).
(DECpc 450ST) using software written in LabView for Windows (National Instrument, Austin, TX). The number of bursts, the total number of spikes in bursts, and variation coefficient of ISI were calculated every $10 \mathrm{sec}$ using Visual Basic macros. The onset of a burst was identified as the concurrence of two spikes with an ISI $<80 \mathrm{msec}$, and the termination of a burst was defined as an ISI $>160 \mathrm{msec}$ (Grace and Bunney, 1984). Only one cell was studied in each rat.

Drugs. All drugs were administered intravenously through a lateral tail vein. Doses were given as salts. Prazosin and phenoxybenzamine were dissolved in 25-30\% polyethylene glycol (PEG) (average molecular weight of $200 \mathrm{kDa}$ ) at $2.5 \mathrm{mg} / \mathrm{ml}$ and $30 \mathrm{mg} / \mathrm{ml}$, respectively. Immediately before injection, the solution was diluted with distilled water so that the final volume of injection was either 0.05 or $0.1 \mathrm{ml}$. Depending on the weight of the animal, the final concentration of PEG ranged from 4.0 to $20 \%$. All other drugs were dissolved in distilled water.

Drugs used in this study and their sources were D-amphetamine sulfate [Research Biochemicals (RBI), Natick, MA], apomorphine $\mathrm{HCl}$ (RBI), raclopride tartrate (Astra, Sodertalje, Sweden), eticlopride $\mathrm{HCl}$ (RBI), (+)SCH-23390 HCl (RBI), prazosin $\mathrm{HCl}$ (RBI), WB4101 HCl (RBI), phenoxybenzamine $\mathrm{HCl}$ (RBI), idazoxan $\mathrm{HCl}$ (Sigma, St. Louis, MO), propranolole $\mathrm{HCl}(\mathrm{RBI})$, nisoxetine $\mathrm{HCl}$ (Tocris Cookson, Ballwin, $\mathrm{MO}$ ), fluoxetine $\mathrm{HCl}(\mathrm{RBI})$, and phenylephrine $\mathrm{HCl}(\mathrm{RBI})$.

Statistics. The statistical significance of the effect of a drug was determined by comparing the activity of the cell before and after drug injection using ANCOVA followed by a post hoc Tukey test. The covariate was the average of $3 \mathrm{~min}$ recordings before the first drug injection (i.e., baseline activity). All numerical data were expressed as mean \pm SEM.

\section{RESULTS}

\section{The initial finding: rebound of DA neurons after raclopride reversal of D-amphetamine- induced inhibition}

In the course of characterizing feedback control of DA neurons, we studied the effect of the selective D2 antagonist raclopride (50 $\mu \mathrm{g} / \mathrm{kg}$ ) on D-amphetamine (1-2 $\mathrm{mg} / \mathrm{kg}$ )-induced inhibition of nigral DA neurons (Shi et al. 2000). As expected, raclopride reversed the inhibition in every cell tested. However, after raclopride, the firing rate of DA cells was always increased to above baseline (Fig. 1). On average, the firing rate was increased from $47.1 \pm 5.2$ spikes/10 sec measured before D-amphetamine to $69.1 \pm 4.8$ spikes/10 sec after raclopride $(n=8)$. Other measures of DA cell activity, including the number of bursts, the number of spikes in bursts, and ISI variation coefficient, were also increased (Fig. 1). Of the four measurements, the number of spikes in bursts was increased the most (from $3.8 \pm 1.6$ to $34.4 \pm 7.5$ spikes $/ 10 \mathrm{sec}$; $n=8)$. These increases were even more significant in nonanesthetized (low cerveau isolé) rats (Fig. $2 A$ ). On average, the firing rate and the number of spikes in bursts were increased from $44.8 \pm 6.1$ to $76.2 \pm 8.7$ spikes $/ 10 \mathrm{sec}$ and from $4.2 \pm 2.5$ to $48.1 \pm$ 13.4 spikes/sec, respectively $(n=6)$. However, when DA cells were inhibited by the direct DA agonist apomorphine (20-40 $\mu \mathrm{g} / \mathrm{kg} ; n=5)$, raclopride $(100 \mu \mathrm{g} / \mathrm{kg})$ simply reversed the inhibition and restored the activity of DA cells to baseline (Fig. 2B). These observations suggest that the increase in DA cell activity, seen after raclopride reversal of D-amphetamine-induced inhibition, is not a rebound phenomenon. Instead, it may be an effect of D-amphetamine revealed by D2 receptor blockade. To further test this conjecture, we performed the following experiments.

\section{Raclopride alone produces only a small increase in DA cell activity}

To test whether raclopride, by blocking the inhibition induced by spontaneously released DA, can lead to a significant excitation of DA cells, rats were given raclopride $(100-200 \mu \mathrm{g} / \mathrm{kg})$ before D-amphetamine. In most cells tested (16 of 22), raclopride produced only a small effect ( $<10 \%$ of baseline) (Fig. $2 C$ ). In the remaining six cells, a $>10 \%$ increase in firing rate was observed (ranging from 11 to $29 \%$ ). Overall, the firing rate was increased from $48.1 \pm 4.0$ to $50.8 \pm 4.0$ spikes/10 $\mathrm{sec}$ after raclopride, whereas the number of spikes in bursts was increased from $7.5 \pm$ 2.8 to $9.7 \pm 3.1 \mathrm{spikes} / 10 \mathrm{sec}(n=22)$. Both increases, although small, were significant (firing rate, $F_{(19.793)}=6.189, p<0.0005$; bursting, $\left.F_{(19,793)}=1.914, p=0.011\right)$.

\section{D-Amphetamine excites DA cells in raclopride-pretreated rats}

To confirm that D-amphetamine has an excitatory effect on DA cells when D2-like receptors are blocked, D-amphetamine (1 


\section{A}

Figure 2. D-Amphetamine excites DA neurons when $\mathrm{D} 2$-like receptors are blocked. $A$, Typical recordings showing that, in a nonanesthetized rat, the activity of a DA cell was also increased after raclopride (Rac) reversal of D-amphetamine (Amph)-induced inhibition. $B$, Recordings from a different DA neuron showing no significant increase in the activity of the cell after raclopride reversal of the direct DA agonist apomorphine (Apo)-induced inhibition. $C$, Recordings from another DA cell showing that raclopride alone produced only a small increase in firing. After raclopride, however, D-amphetamine significantly increased both firing rate and bursting. $D$, Recordings from still another DA neuron showing that the excitatory effect of D-amphetamine persisted after both D1- and D2-like receptors were blocked by $\mathrm{SCH} 23390(\mathrm{SCH})$ and eticlopride (Etic).

C
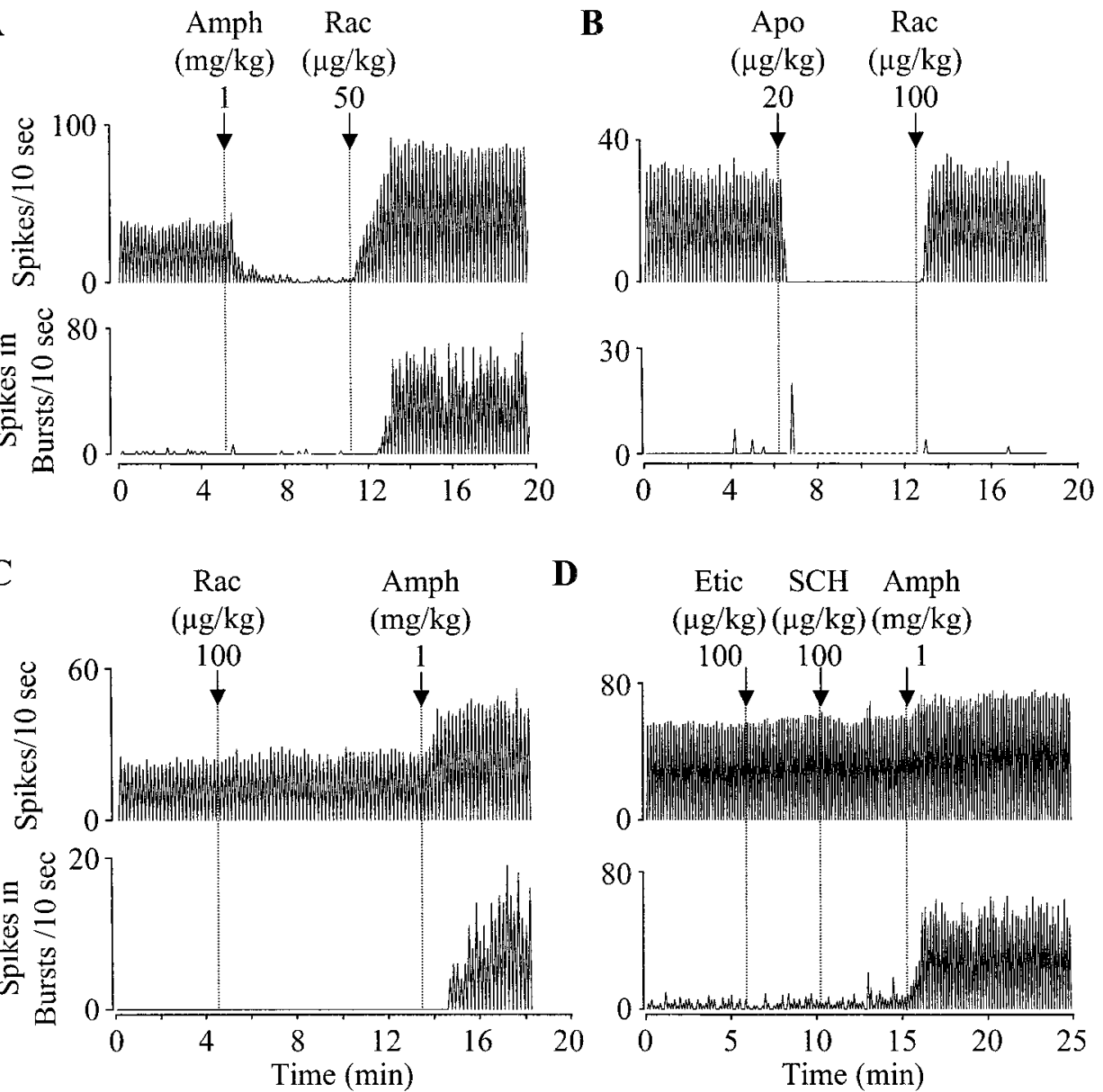

D

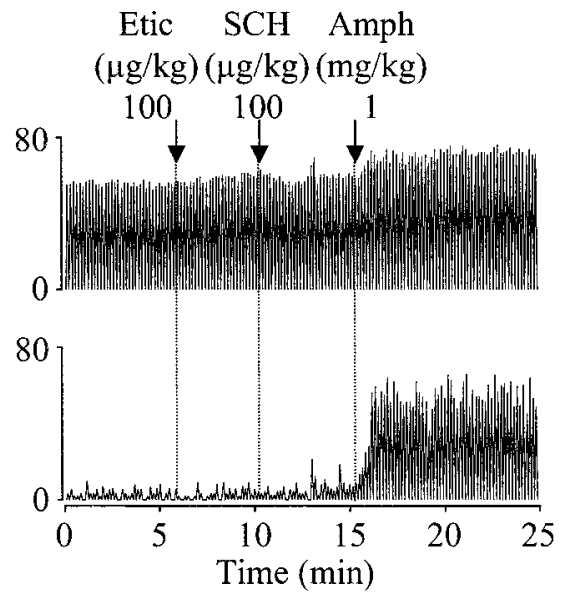

$\mathrm{mg} / \mathrm{kg}$ ) was administered after raclopride $(100-200 \mu \mathrm{g} / \mathrm{kg})$. In nearly all cells tested (21 of 22 ), D-amphetamine produced a marked excitation (Fig. 2C); most cells showed an increase in both firing rate and bursting $(n=15)$, whereas the remaining cells showed ether an increase in bursting only $(n=4)$ or an increase in firing rate only $(n=2)$. In one cell, D-amphetamine produced no effect on firing rate and decreased burst activity by $25 \%$. Altogether, firing rate was increased from $50.8 \pm 4.0$ to $62.3 \pm 3.4$ spikes/10 sec, and the number of spikes in bursts was increased from $9.7 \pm 3.1$ to $27.3 \pm 4.2$ spikes/10 $\sec (n=22)$. Both increases were highly significant (firing, $F_{(19,793)}=26.9, p<0.0005$; bursting, $\left.F_{(19,793)}=9.5, p<0.0005\right)$.

A similar excitatory effect of D-amphetamine was observed in VTA DA neurons. Thus, after raclopride (50-100 $\mu \mathrm{g} / \mathrm{kg}$ ), D-amphetamine $(1 \mathrm{mg} / \mathrm{kg})$ increased both firing rate and bursting in seven of eight cells tested. In the remaining cell, D-amphetamine produced no effect on either measurement. On average, the firing rate was increased from $60.6 \pm 6.6$ to $73.2 \pm$ 7.3 spikes $/ 10 \mathrm{sec}$, and the number of spikes in bursts was increased from $32.3 \pm 10.6$ to $52.3 \pm 11.7$ spikes/10 sec $(n=8)$. Both changes induced by D-amphetamine were statistically significant (firing rate, $F_{(19,275)}=5.015, p<0.0005$; bursting, $F_{(19,275)}=$ $3.255, p<0.0005)$.

\section{D-Amphetamine-induced excitation persists after both D1 and D2-like receptors are blocked}

By releasing DA, D-amphetamine activates all five subtypes of DA receptors $\left(D_{1}-D_{5}\right)$. Raclopride, however, blocks mainly $D_{2}$ and $\mathrm{D}_{3}$ receptors (Van Tol et al., 1991). To test whether
D-amphetamine excites DA cells through $\mathrm{D}_{1}, \mathrm{D}_{4}$, or $\mathrm{D}_{5}$ receptors, rats were pretreated with eticlopride $(0.1 \mathrm{mg} / \mathrm{kg})$ and SCH23390 $(0.1 \mathrm{mg} / \mathrm{kg})$. The former blocks all three subtypes of D2-like receptors $\left(D_{2}, D_{3}\right.$, and $\left.D_{4}\right)$, whereas the latter blocks both $D_{1}$ and $\mathrm{D}_{5}$ receptors. In all five animals tested, D-amphetamine $(1 \mathrm{mg} /$ $\mathrm{kg}$ ), injected after eticlopride and SCH23390, markedly excited DA cells (Fig. 2D). On average, the firing rate was increased from $47 \pm 7$ to $63 \pm 6$ spikes/10 sec, whereas the number of spikes in bursts was increased from $6.6 \pm 2.2$ to $26 \pm 8.2$ spikes $/ 10$ sec. Both increases were highly significant (firing rate, $F_{(19,164)}=17.7, p<$ 0.0005; bursting, $\left.F_{(19,164)}=14.1, p<0.0005\right)$.

\section{Adrenergic $\alpha 1$ antagonists partially blocks D-amphetamine-induced excitation}

To determine whether part of the excitation induced by D-amphetamine involves activation of adrenergic receptors, the effect of the $\alpha 1$ antagonist prazosin was examined. In five of nine cells tested, prazosin alone $(1 \mathrm{mg} / \mathrm{kg})$ produced a small effect on firing rate ( $<10 \%$ of baseline) (Fig. $3 A$ ). In three of nine cells, prazosin increased firing 11,12 , and $30 \%$, respectively. In the remaining cell, the firing rate was decreased $10 \%$. Overall, the firing rate was changed from $46.1 \pm 5.2$ to $47.7 \pm 4.7$ spikes $/ 10 \mathrm{sec}$ after prazosin. The number of spikes in bursts was unchanged by prazosin (from $1.1 \pm 0.5$ to $1.1 \pm 0.6 \mathrm{spikes} / 10 \mathrm{sec} ; n=9$ ).

Pretreatment with prazosin, however, blocked the burst increasing effect of D-amphetamine (Fig. 3A,D). In all seven prazosin-treated rats, D-amphetamine $(1 \mathrm{mg} / \mathrm{kg})$, injected after raclopride $(100 \mu \mathrm{g} / \mathrm{kg})$, produced no effect on bursting (from $7.3 \pm 4.5$ to $7.3 \pm 2.9$ spikes in bursts $/ 10 \mathrm{sec} ; F_{(19,238)}=0.696 ; p=$ 
$\mathbf{A}$

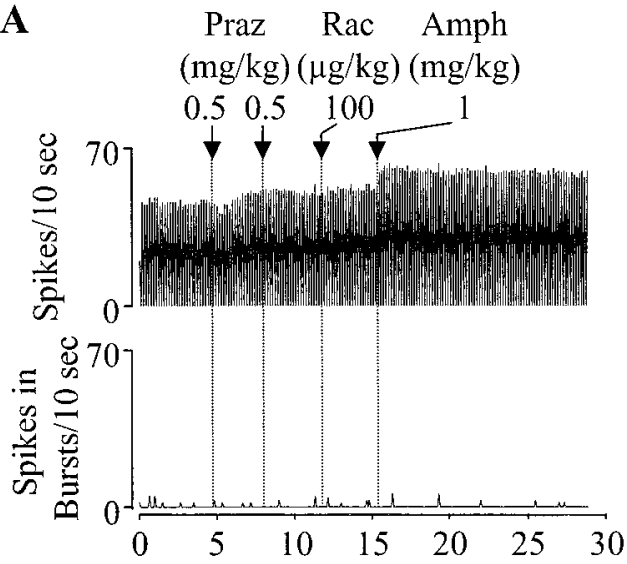

C

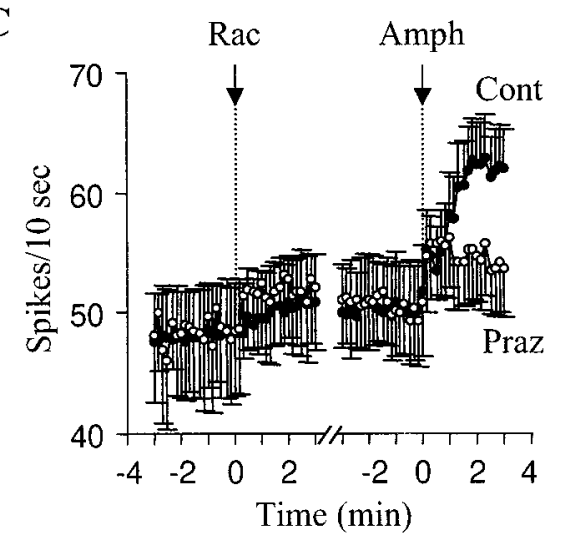

B
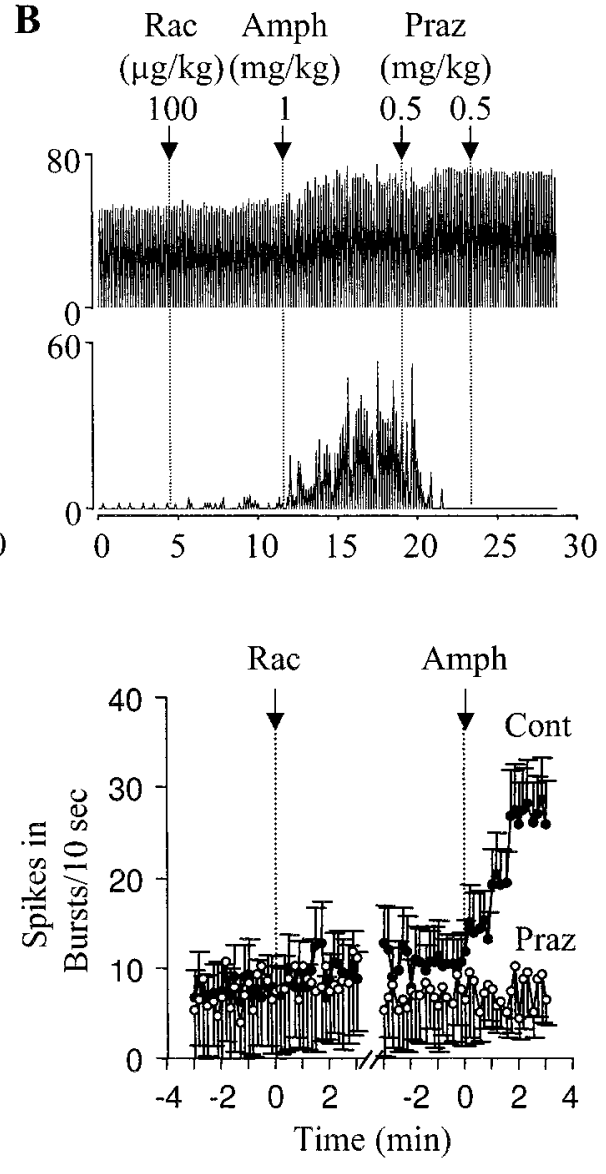

Figure 3. The $\alpha 1$ antagonist prazosin blocks D-amphetamine-induced bursting of DA cells. $A$, Typical recordings from a DA neuron showing that pretreatment with prazosin (Praz) completely blocked the ability of D-amphetamine [Amph; injected after raclopride (Rac)] to increase bursting. In the same cell, however, D-amphetamine was still able to induce a small increase in firing rate. $B$, Recordings from a different DA cell showing that prazosin completely reversed $\mathrm{D}$-amphetamine-induced increase in bursting and transiently reversed the increase in firing rate. $C$, Summary of data showing the differences between the effects of D-amphetamine in control (filled circles; $n=$ 22) and prazosin-pretreated rats (open circles; $n=7)$. Prazosin pretreatment partially blocked the increase in firing rate (left) and completely blocked the increase in bursting (right) induced by D-amphetamine $(1 \mathrm{mg} / \mathrm{kg}$, injected after 50 $200 \mu \mathrm{g} / \mathrm{kg}$ of raclopride; see Results for detailed statistics).
$0.821 ; n=7$ ) (Fig. $3 C$ ). In the same cells, D-amphetamine was still able to induce a small increase in firing rate $(50.7 \pm 3.9$ to $55.1 \pm$ 4.0 spikes $\left./ 10 \mathrm{sec} ; F_{(19,238)}=2.2 ; p<0.005\right)$ (Fig. $3 C$ ).

In 10 other cells, prazosin $(1 \mathrm{mg} / \mathrm{kg})$ was given after D-amphetamine ( $1 \mathrm{mg} / \mathrm{kg}$, after $50-100 \mu \mathrm{g} / \mathrm{kg}$ of raclopride). In 7 of 10 cells, the increase in firing induced by D-amphetamine was unaffected or only transiently reversed by prazosin (Fig. $3 B$ ). In two cells, the increase was completely reversed by prazosin. In the remaining cell, prazosin partially reversed D-amphetamineinduced increase in firing $(69 \%)$. The increase in bursting, however, was completely reversed by prazosin in most cells tested ( 8 of 10 ) (Fig. $3 B$ ). In the remaining two cells, a partial reversal was observed (37 and 64\%, respectively).

Similar blocking effects were observed with another $\alpha 1$ antagonist, WB4101. In seven rats pretreated with WB4101 $(0.2 \mathrm{mg} /$ $\mathrm{kg})$, D-amphetamine $(1 \mathrm{mg} / \mathrm{kg})$ after raclopride $(100 \mu \mathrm{g} / \mathrm{kg})$ increased the firing rate in four cells (ranging from 11 to $25 \%$ of baseline), decreased the rate in one cell $(11 \%)$, and produced no effect in the remaining two cells. Overall, the firing rate was increased from $49 \pm 4$ to $53 \pm 4$ spikes $/ 10 \sec \left(F_{(19,238)}=0.673\right.$; $p=0.844)$. In all seven cells, the effect of D-amphetamine on bursting was completely blocked (from $6 \pm 3$ to $4 \pm 2$ spikes in bursts $\left./ 10 \mathrm{sec} ; F_{(19,238)}=0.985 ; p=0.48\right)$. In 10 other cells, WB4101 $(0.05-0.2 \mathrm{mg} / \mathrm{kg})$ was given after raclopride $(0.1 \mathrm{mg} / \mathrm{kg})$ and D-amphetamine $(1 \mathrm{mg} / \mathrm{kg})$. In 6 of 10 cells, the increase in firing induced by D-amphetamine was completely reversed by WB4101. In two cells, the increase was partially reversed (77 and $79 \%$, respectively). In the two remaining cells, only a transient reversal was observed. In all cells, the increase in bursting was completely reversed by WB4101.
Phenoxybenzamine blocks both $\alpha 1$ and $\alpha 2$ receptors. Like prazosin and WB4101, phenoxybenzamine partially blocked the increase in firing rate and completely blocked the increase in bursting induced by D-amphetamine. Thus, in eight cells pretreated with phenoxybenzamine $(1 \mathrm{mg} / \mathrm{kg})$, D-amphetamine (1 $\mathrm{mg} / \mathrm{kg})$ after raclopride $(0.1 \mathrm{mg} / \mathrm{kg})$ increased the firing rate in four cells (ranging from 12 to $39 \%$ ), decreased the rate in one cell $(24 \%)$, and produced no effect in remaining three cells $(<10 \%$ of baseline). In all cells, the burst increasing effect of D-amphetamine was completely blocked (from $1 \pm 1$ to $1 \pm 1$ spikes/10 sec). In 10 other cells, phenoxybenzamine (1-2 mg/kg) was administered after raclopride $(0.1 \mathrm{mg} / \mathrm{kg})$ and D-amphetamine $(1 \mathrm{mg} / \mathrm{kg})$. In three of the cells, the increase in firing induced by D-amphetamine was completely reversed by phenoxybenzamine. In the remaining cells, it was either partially reversed ( $n=5$; ranging from 47 to $80 \%$ ) or not affected by phenoxybenzamine $(n=1)$. In nine cells in which D-amphetamine produced a significant increase in bursting, phenoxybenzamine completely reversed the effect in seven cells and partially reversed the effect in two remaining cells (68 and 78\%, respectively).

Both prazosin and phenoxybenzamine were dissolved in a PEG solution (4-20\%). To test whether PEG has an effect on D-amphetamine-induced excitation, a solution containing PEG only $(25-30 \%, 0.1 \mathrm{ml})$ was injected after raclopride and D-amphetamine. In all 10 cells tested, no significant effect was observed. In the same cells, subsequent injection of prazosin $(n=$ 3 ) or phenoxybenzamine $(n=7)$ reversed the excitation, especially the increase in bursting.

Unlike $\alpha 1$ antagonists, the $\alpha 2$ antagonist idaxozan $(2 \mathrm{mg} / \mathrm{kg})$ 
Figure 4. The selective NE uptake blocker nisoxetine increases DA cell bursting. $A$, Typical recordings from a DA cell showing that nisoxetine (Nis) alone produced a significant increase in bursting and a small and transient increase in firing rate. Raclopride (Rac) after nisoxetine further increased firing rate and bursting. The 5-HT uptake blocker fluoxetine $(F l u)$ produced no further effect. Prazosin (Praz) reversed the increase in DA cell activity induced by both nisoxetine and raclopride. $B$, Recordings from a different DA cell showing that the 5-HT uptake blocker fluoxetine produced no significant effect on either firing rate or bursting. Subsequent injection of raclopride also failed to produce a significant effect. $C$, Summary of data from all 12 cells tested with nisoxetine $(2-5 \mathrm{mg} / \mathrm{kg})$ followed by raclopride $(0.1 \mathrm{mg} / \mathrm{kg})$. Nisoxetine had no significant effect on firing rate (left); it, however, significantly increased the number of spikes in bursts (right). Raclopride injection further increased both firing rate and bursting (see Results for detailed statistics).

C
A
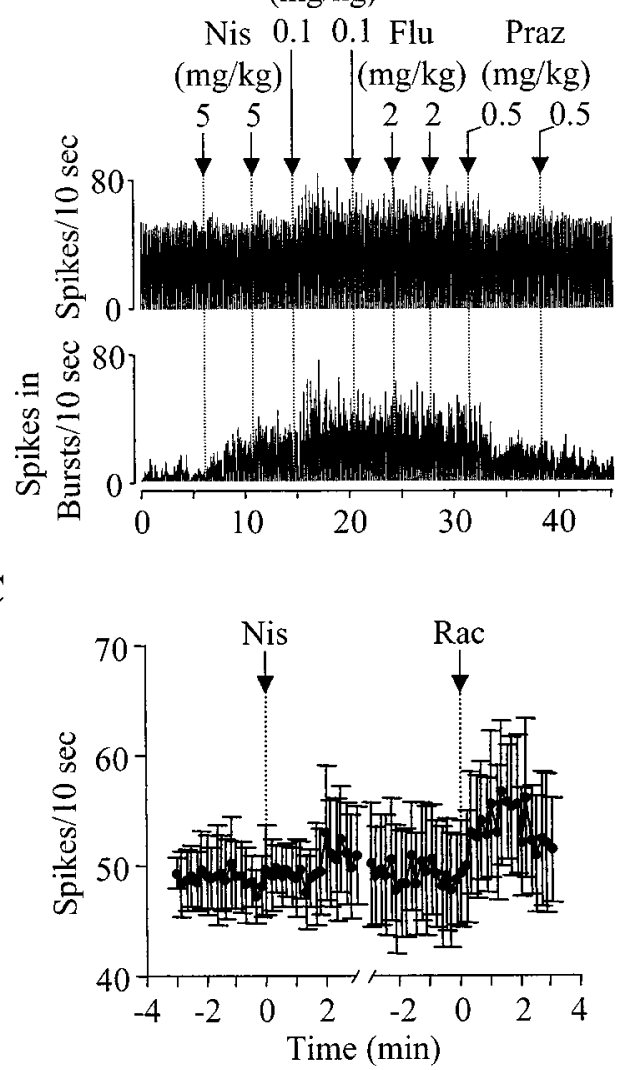

B


and the $\beta$ antagonist propranolol $(2 \mathrm{mg} / \mathrm{kg}$ ) failed to prevent $\mathrm{D}$-amphetamine from producing the excitation. In five cells treated with idazoxan, D-amphetamine $(1 \mathrm{~m} / \mathrm{kg})$ after raclopride $(100 \mu \mathrm{g} / \mathrm{kg})$ increased firing rate from $48.3 \pm 6.2$ to $61.6 \pm 7.3$ spikes/10 sec and the number of spikes in bursts from $4.3 \pm 2.7$ to $22.1 \pm 11.6$ spikes $/ 10 \mathrm{sec}$. In five other cells treated with propranolol, D-amphetamine $(1 \mathrm{mg} / \mathrm{kg})$ increased the firing rate from $40.9 \pm 7.6$ to $58.7 \pm 14.3$ spikes/10 sec and the number of spikes in bursts from $3.0 \pm 1.4$ to $28.4 \pm 20.3$ spikes/10 sec. These increases were statistically not different from those observed in rats pretreated with raclopride only (idaxozan: firing rate, $F_{(1,24)}=$ $0.154, p=0.7$; bursting, $F_{(1,24)}=0.008, p=0.92$; propranolole: firing rate, $F_{(1,24)}=0.593, p=0.45$; bursting, $F_{(1,24)}=0.294, p=$ 0.59 ; all compared with corresponding measures in rats pretreated with raclopride only).

\section{The selective norepinephrine uptake blocker nisoxetine mimics the excitatory effect of D-amphetamine}

To test further whether selective blockade of norepinephrine (NE) uptake mimics the effect of D-amphetamine, nisoxetine (5-10 $\mathrm{mg} / \mathrm{kg}$, i.v.) was administered. In 8 of 12 cells tested, nisoxetine alone increased the activity of the cell (Fig. $4 A$ ). In the four remaining cells, nisoxetine produced either a slight decrease or no effect on the activity of the cell. Of the eight cells excited by nisoxetine, five showed an increase in bursting only, two showed an increase in both firing rate and bursting, and one in firing only. Overall, the firing rate was unchanged by nisoxetine (from $49 \pm$ 3.6 to $49 \pm 3.9$ spikes $\left./ 10 \mathrm{sec} ; F_{(19,423)}=0.38 ; p=0.99 ; n=12\right)$, whereas the number spikes in bursts was significantly increased (from $4.5 \pm 3$ to $15 \pm 4.8 \mathrm{spikes} / 10 \mathrm{sec} ; F_{(19,423)}=6.8 ; p<0.0005$; $n=12)$ (Fig. $4 C)$. Subsequent raclopride injection $(0.2 \mathrm{mg} / \mathrm{kg})$ further increased both firing rate and bursting in five cells and bursting only in three cells. On average, raclopride increased the firing rate from $49 \pm 4.3$ to $53 \pm 3.8$ spikes $/ 10 \sec \left(F_{(19,423)}=1.9\right.$; $p<0.01 ; n=12)$ and the number of spikes in bursts from $15 \pm$ 4.9 to $22 \pm 5.4$ spikes $/ 10 \sec \left(F_{(19,423)}=1.2 ; p=0.23 ; n=12\right)$.

In six other cells, raclopride was administered before nisoxetine. In most cells (five of six), raclopride alone induced a small increase in firing rate ( $<10 \%$ of baseline). In one cell, raclopride increased bursting from 33 to 44 spikes/10 sec. In five of six raclopride-treated cells, nisoxetine increased bursting. In four cells, this increase in bursting was accompanied with no changes in firing rate. In one cell, firing rate was also increased. In the remaining cell, nisoxetine produced no significant effects. Overall, nisoxetine increased firing rate from $46 \pm 7.7$ to $50 \pm 7.9$ spikes $/ 10 \sec \left(F_{(19,201)}=1.4 ; p=0.11\right)$ and the number of spikes in bursts from $8.5 \pm 7.9$ to $20 \pm 9.5$ spikes $/ 10 \sec \left(F_{(19,201)}=3.9\right.$; $p<0.0005)$.

To test whether selective blockade of 5-HT uptake also mimics the effect of D-amphetamine, fluoxetine $(4 \mathrm{mg} / \mathrm{kg}$ ) was administered. Of the six cells tested, five showed no significant changes after fluoxetine injection (Fig. 4B). The remaining cell showed a decrease in both firing rate and bursting (from 67 to 56 and 44 to 16 spikes/10 sec, respectively). Overall, the firing rate was reduced from $58 \pm 6.2$ to $56 \pm 6.1$ spikes $/ 10 \sec \left(F_{(19,201)}=1.8 ; p=0.024\right)$, and the number of spikes in bursts was also slightly reduced from $18 \pm 8.2$ to $15 \pm 6.7$ spikes $/ 10 \sec \left(F_{(19,201)}=0.75 ; p=0.76\right)$.

In nine other cells, fluoxetine was administered after raclopride $(0.2 \mathrm{mg} / \mathrm{kg})$. Six of the cells showed no change, two showed an increase in bursting (from 14 to 24 and from 1.4 to 5.9 spikes/10 


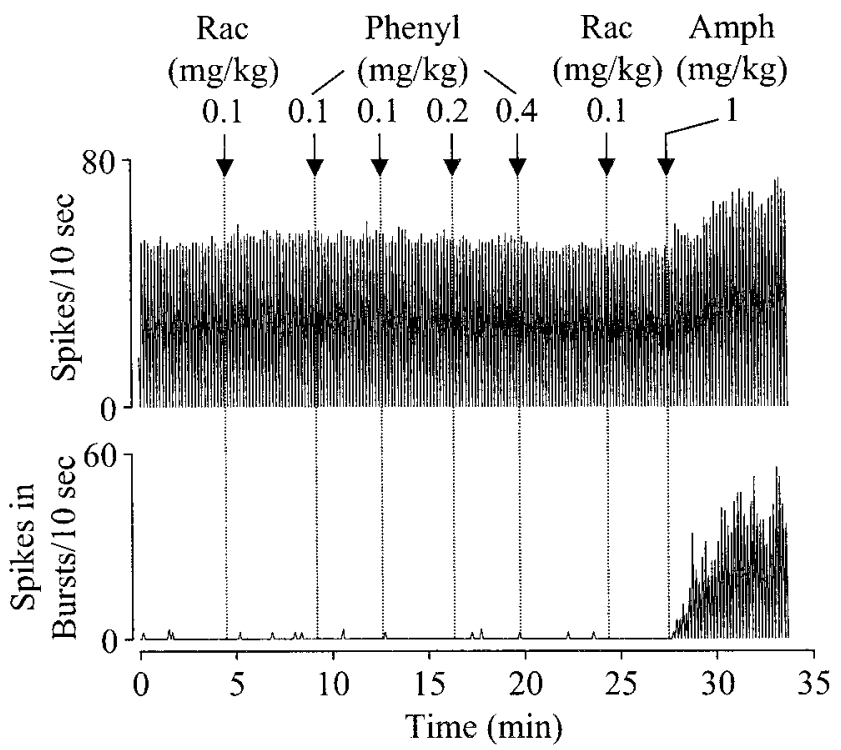

Figure 5. Effects of peripheral activation of $\alpha 1$ receptors on DA neurons. Typical recordings showing that intravenous injection of phenylephrine (Phenyl) produced no effect on bursting and a small decrease in firing rate. In the same cell, subsequent injection of D-amphetamine (Amph) markedly increased both firing rate and bursting. Rac, Raclopride

sec, respectively), and the remaining cell showed a decrease in bursting (from 11 to $1.4 \mathrm{spikes} / 10 \mathrm{sec}$ ). On average, the firing rate was slightly decreased by fluoxetine (from $57 \pm 3.3$ to $56 \pm 3.1$ spikes/10 sec), whereas the number spikes in bursts was slightly increased (from $15 \pm 2.8$ to $16 \pm 3.2$ spikes/10 sec). Both changes were statistically insignificant (firing rate, $F_{(19,312)}=0.56, p=$ 0.93 ; bursting, $\left.F_{(19,312)}=0.84, p=0.66\right)$.

To test whether fluoxetine excites DA cells when both $\mathrm{NE}$ uptake and D2-like receptors are blocked, rats were given nisoxetine $(10 \mathrm{mg} / \mathrm{kg})$ and raclopride $(0.2 \mathrm{mg} / \mathrm{kg})$, and then fluoxetine $(4-8 \mathrm{mg} / \mathrm{kg})$. In seven of nine cells tested, fluoxetine produced no significant effect (Fig. 4A). In one cell, however, both firing rate and bursting were increased after fluoxetine (firing rate, from 47 to 58 spikes/10 sec; bursting, from 21 to 45 spikes/10 sec). In the remaining cell, fluoxetine increased firing rate only (from 58 to 71 spikes/10 sec). Overall, the effects of fluoxetine were insignificant (firing rate, from $53 \pm 4.1$ to $56 \pm 4.3, F_{(19,312)}=1.2, p=0.25$; bursting, from $21 \pm 6.5$ to $27 \pm 7.4, F_{(19,312)}=0.697, p=0.82$ ).

\section{The prepheral $\alpha 1$ agonist phenylephrine does not mimic the excitatory effect of $\mathrm{D}$-amphetamine}

When administered systemically, D-amphetamine increases NE release both peripherally and centrally. To test whether peripheral $\alpha 1$ receptors play a role in $\mathrm{D}$-amphetamine-induced excitation of DA cells, phenylephrine was administered intravenously. Unlike D-amphetamine, phenylephrine $(0.8 \mathrm{mg} / \mathrm{kg})$, injected either alone or after raclopride $(0.1 \mathrm{mg} / \mathrm{kg})$, produced only a small effect on DA cells (Fig. 5). On average, the firing rate was slightly decreased (from $47 \pm 6$ to $46 \pm 6$ spikes/10 sec; $n=6$ ), whereas the number of spikes in bursts was slightly increased (from $1 \pm 0.4$ to $3.1 \pm 1.8 \mathrm{spikes} / 10 \mathrm{sec} ; n=6)$. In these same cells, subsequent injection of D-amphetamine $(1 \mathrm{mg} / \mathrm{kg})$ markedly increased both firing rate (from $46 \pm 7$ to $64 \pm 9$ spikes $/ 10 \mathrm{sec} ; F_{(19,201)}=13.9$; $p<0.0005$ ) and bursting (from $3.7 \pm 2.2$ to $28.7 \pm 13.8$ spikes/10 sec; $\left.F_{(19,201)}=3.9 ; p<0.0005\right)$.

\section{DISCUSSION}

The present study shows that systemic administration of D-amphetamine has two opposing effects on DA neurons: a DAmediated feedback inhibition and a non-DA-mediated excitation. Evidence further suggests that the excitatory effect is mediated in part through adrenergic $\alpha 1$ receptors.

The inhibitory effect of D-amphetamine on DA cells has been extensively studied. Evidence suggests that the effect involves release of endogenous DA and activation of DA receptors (Bunney and Aghajanian, 1976, 1978; Shi et al., 2000). Supporting the suggestion, DA antagonists, such as raclopride, readily reverse the inhibition induced by D-amphetamine. In this study, we found that, after raclopride reversal of D-amphetamine-induced inhibition, the activity of DA cells, instead of returning to baseline, was markedly increased to above baseline. A similar increase has been observed previously with other DA antagonists (Bunney et al., 1973). The effect, however, was not further characterized because it was thought to be a simple rebound of the cell or to be attributable to blockade of a tonic DA inhibition induced by spontaneous DA release. The present study suggests that neither mechanism contributes significantly to the effect because (1) no significant rebound was observed when raclopride was used to reverse the inhibition induced by the direct DA agonist apomorphine and (2) raclopride alone, by blocking the inhibition induced by spontaneous DA release, produced only a small increase in DA cell activity. The finding that D-amphetamine consistently and significantly excites DA cells in raclopride-pretreated rats further suggests that the increase in DA cell activity, seen after raclopride reversal of D-amphetamine-induced inhibition, is primarily mediated by an excitatory effect of D-amphetamine revealed by raclopride.

D-Amphetamine, by releasing endogenous DA, should activate all subtypes of DA receptors $\left(D_{1}-D_{5}\right)$. Raclopride, however, blocks mainly $\mathrm{D}_{2}$ and $\mathrm{D}_{3}$ receptors, raising the possibility that D-amphetamine excites DA cells through DA receptors not blocked by raclopride, i.e., $\mathrm{D}_{1}, \mathrm{D}_{4}$, or $\mathrm{D}_{5}$ receptors. Our results suggest, however, that $\mathrm{D}$-amphetamine-induced excitation is not a DA receptor-mediated effect because it persisted after injections of both SCH23390 and eticlopride, a treatment that should block all subtypes of DA receptors. The excitation was largely blocked, however, by adrenergic $\alpha 1$ antagonists and was mimicked by the selective NE uptake blocker nisoxetine, suggesting that it is mediated in part through $\alpha 1$ receptors. This suggestion is consistent with previous studies showing that electrical stimulation of the locus ceruleus excites DA neurons (Collingridge et al., 1979; Grenhoff et al., 1993) and that the excitation is reduced by the $\alpha 1$ antagonist prazosin (Grenhoff et al., 1993).

D-Amphetamine also binds to 5-HT uptake transporters. The affinity, however, is lower compared with that for DA or NE transporters (Ritz and Kuhar, 1989). The present study suggests that 5-HT is not critical in D-amphetamine-induced excitation because, unlike nisoxetine, the selective 5-HT uptake blocker fluoxetine produced no significant effect on DA cells when injected either before or after raclopride. A lack of an effect of fluoxetine on DA cells has been reported previously (Einhorn et al., 1988). In one study, fluoxetine was shown to inhibit VTA DA cells without altering the activity of SN DA cells (Prisco and Esposito, 1995). In this study, we also showed that the effect of $\mathrm{D}$-amphetamine persisted in the presence of the adrenergic $\beta$ receptor antagonist propranolol, which blocks also 5-HT1A and 5-HT1B receptors (Alexander and Wood, 1987). In preliminary 
experiments, the 5-HT2 antagonist ritanserine was found to also have no effect on D-amphetamine-induced excitation.

During D-amphetamine-induced excitation, most cells showed increases in both firing rate and bursting. Several observations suggest that two changes may be mediated by different mechanisms. Thus, in many cells, the increase in firing rate was only partially blocked or not affected by an $\alpha 1$ antagonist, whereas in the same cells, the increase in bursting was completely reversed by the antagonist. In more than half of the cells tested, nisoxetine increased bursting without a significant effect on firing rate. In a previous study, prazosin was shown to decrease spontaneous bursting of VTA DA cells without altering the firing rate (Grenhoff and Svensson, 1993). These results suggest that the increase in bursting induced by D-amphetamine is mediated by $\alpha 1$ receptors, whereas the increase in firing rate involves activation of other receptors as well.

When administered systemically, D-amphetamine increases release of NE both peripherally and centrally. Our data suggest that the excitatory effect of D-amphetamine is centrally mediated because (1) the effect persisted after a complete brainstem transection, which should block all visceral input as well as most somatosensory input to the brain, and (2) selective activation of peripheral $\alpha 1$ receptors by intravenous injection of phenylephrine failed to mimic the effect of D-amphetamine. In a previous study in brain slices, application of phenylephrine directly to DA cells induced a depolarization in a subset of cells tested (Grenhoff et al., 1995), suggesting that part of the excitation induced by D-amphetamine may be mediated by $\alpha 1$ receptors on DA cells. D-Amphetamine may, however, also produce some of its effect indirectly through brain areas that receive $\mathrm{NE}$ input and project to DA cells. Consistent with this suggestion, in a preliminary study, we have shown that forebrain transection rostral to the substantia nigra completely blocked the increase in bursting and partially blocked the increase in firing induced by D-amphetamine (Zhang et al., 1999). Several brain areas may contribute to the excitatory effect of D-amphetamine, including the prefrontal cortex and the amygdala. A potential role for the prefrontal cortex is suggested by the study by Darracq et al. (1998) in which prazosin, injected either systemically or locally in the prefrontal cortex, reversed the increase in DA release as well as in locomotor activity induced by systemic D-amphetamine. Direct stimulation of the prefrontal cortex has also been shown to increase DA cell activity, especially bursting (Gariano and Groves, 1988; Murase et al., 1993; Tong et al., 1996).

The finding that D-amphetamine excites DA cells in part through adrenergic receptors may have important clinical implications. In preliminary studies, we have found that the excitatory effect of D-amphetamine is mimicked by all psychostimulants tested, including cocaine, methamphetamine, and methylphenidate (Shi et al., 1999). In the absence of raclopride, however, these drugs inhibit DA cells, suggesting that DA-mediated feedback inhibition is the dominant effect under normal conditions. After chronic administration with D-amphetamine or cocaine, DA-mediated inhibition has been shown to be transiently reduced (White and Wang, 1984; Henry et al., 1998) or increased (Gao et al., 1998). However, because these studies were performed in chloral hydrate-anesthetized preparations and because chloral hydrate anesthesia alters feedback mechanisms of DA cells (Shi et al., 1997b, 2000), it is possible that not all effects induced by chronic psychostimulants were observed in these studies. Supporting this suggestion, a study performed in nonanesthetized rats reported that D-amphetamine excited half of VTA DA cells in rats chronically treated with D-amphetamine (Kamata and Rebec, 1984). Thus, non-DA-mediated excitation may become the dominant effect of psychostimulants on DA neurons in chronically treated animals.

Pathways responsible for the adrenergic excitation of DA neurons may be activated by mechanisms other than psychostimulants. It is well known that NE neurons in the locus ceruleus are particularly sensitive to stress (Abercrombie and Jacobs, 1987; Stone and Zhang, 1995). Stress also activates DA cells (Finlay and Zigmond, 1997). The presence of an adrenergic influence on DA neurons suggests that part of stress-induced excitation of DA cells may be mediated through NE neurons. Thus, a better understanding of the NE-DA interaction may provide new insights into not only psychostimulant-related drug addiction but also stress-related disorders, including anxiety, schizophrenia, and depression.

\section{REFERENCES}

Abercrombie ED, Jacobs BL (1987) Single-unit response of noradrenergic neurons in the locus coeruleus of freely moving cats. I. Acutely presented stressful and nonstressful stimuli. J Neurosci 7:2837-2843.

Alexander BS, Wood MD (1987) Stereoselective blockade of central $\left[{ }^{3} \mathrm{H}\right] 5$-hydroxytryptamine binding to multiple sites (5-HT1A, 5-HT1B and 5-HT1C) by mianserin and propranolol. J Pharm Pharmacol 39:664-666.

Bunney BS, Aghajanian GK (1976) d-Amphetamine-induced inhibition of central dopaminergic neurons: mediation by a striato-nigral feedback pathway. Science 192:391-393.

Bunney BS, Aghajanian GK (1978) d-Amphetamine-induced depression of central dopamine neurons: evidence for mediation by both autoreceptors and a striato-nigral feedback pathway. Naunyn Schmiedebergs Arch Pharmacol 304:255-261.

Bunney BS, Walters JR, Roth RH, Aghajanian GK (1973) Dopaminergic neurons: effect of antipsychotic drugs and amphetamine on single cell activity. J Pharmacol Exp Ther 185:560-571.

Collingridge GL, James TA, MacLeod NK (1979) Neurochemical and electrophysiological evidence for a projection from the locus coeruleus to the substantia nigra. J Physiol (Lond) 290:44P.

Darracq L, Blanc G, Glowinski J, Tassin JP (1998) Importance of the noradrenaline-dopamine coupling in the locomotor activating effects of D-amphetamine. J Neurosci 18:2729-2739.

Einhorn LC, Johansen PA, White FJ (1988) Electrophysiological effects of cocaine in the mesoaccumbens dopamine system: studies in the ventral tegmental area. J Neurosci 8:100-112.

Finlay JM, Zigmond MJ (1997) The effects of stress on central dopaminergic neurons: possible clinical implications. Neurochem Res 22:1387-1394.

Gao WY, Lee TH, King GR, Ellinwood EH (1998) Alterations in baseline activity and quinpirole sensitivity in putative dopamine neurons in the substantia nigra and ventral tegmental area after withdrawal from cocaine pretreatment. Neuropsychopharmacology 18:222-232.

Gariano RF, Groves PM (1988) Burst firing induced in midbrain dopamine neurons by stimulation of the medial prefrontal and anterior cingulate cortices. Brain Res 462:194-198.

Grace AA, Bunney BS (1980) Nigral dopamine neurons: intracellular recording and identification with L-dopa injection and histofluorescence. Science 210:654-656.

Grace AA, Bunney BS (1983) Intracellular and extracellular electrophysiology of nigral dopaminergic neurons. I. Identification and characterization. Neuroscience 10:301-315.

Grace AA, Bunney BS (1984) The control of firing pattern in nigral dopamine neurons: burst firing. J Neurosci 4:2877-2890.

Grenhoff J, Svensson TH (1993) Prazosin modulates the firing pattern of dopamine neurons in rat ventral tegmental area. Eur J Pharmacol 233:79-84.

Grenhoff J, Nisell M, Ferre S, Aston-Jones G, Svensson TH (1993) Noradrenergic modulation of midbrain dopamine cell firing elicited by stimulation of the locus coeruleus in the rat. J Neural Transm Gen Sect 93:11-25.

Grenhoff J, North RA, Johnson SW (1995) Alpha 1-adrenergic effects on dopamine neurons recorded intracellularly in the rat midbrain slice. Eur J Neurosci 7:1707-1713. 
Henry DJ, Hu XT, White FJ (1998) Adaptations in the mesoaccumbens dopamine system resulting from repeated administration of dopamine D1 and D2 receptor-selective agonists: relevance to cocaine sensitization. Psychopharmacology (Berl) 140:233-242.

Kamata K, Rebec GV (1984) Long-term amphetamine treatment attenuates or reverses the depression of neuronal activity produced by dopamine agonists in the ventral tegmental area. Life Sci 34:2419-2427.

Lee TH, Gao WY, Davidson C, Ellinwood EH (1999) Altered activity of midbrain dopamine neurons following 7-day withdrawal from chronic cocaine abuse is normalized by $\mathrm{D} 2$ receptor stimulation during the early withdrawal phase. Neuropsychopharmacology 21:127-136.

Murase S, Grenhoff J, Chouvet G, Gonon FG, Svensson TH (1993) Prefrontal cortex regulates burst firing and transmitter release in rat mesolimbic dopamine neurons studied in vivo. Neurosci Lett 157:53-56.

Prisco S, Esposito E (1995) Differential effects of acute and chronic fluoxetine administration on the spontaneous activity of dopaminergic neurones in the ventral tegmental area. Br J Pharmacol 116:1923-1931.

Ritz MC, Kuhar MJ (1989) Relationship between self-administration of amphetamine and monoamine receptors in brain: comparison with cocaine. J Pharmacol Exp Ther 248:1010-1017.

Shi WX, Pun CL, Jones M, Bunney BS (1997a) An $\alpha 1$-mediated adrenergic excitation of midbrain dopamine neurons: activated by d-amphetamine and blocked by antipsychotic drugs. American College of Neuropsychopharmacology 36th Annual Meeting Abstracts 311.

Shi WX, Smith PL, Pun CL, Millet B, Bunney BS (1997b) D1-D2 interaction in feedback control of midbrain dopamine neurons. J Neurosci 17:7988-7994.
Shi WX, Pun CL, Jones M, Bunney BS (1998) d-Amphetamine-induced excitation of midbrain DA neurons: an effect mediated by $\alpha 1$ receptors. Soc Neurosci Abstr 24:249.

Shi WX, Pun C-L, Zhang X-X, Smith PL, Jones MD (1999) Opposite effects of psychostimulants on DA neurons mediated by DA and non-DA receptors. Soc Neurosci Abstr 25:1820.

Shi WX, Pun C-L, Smith PL, Bunney BS (2000) Endogenous DAmediated feedback inhibition of midbrain DA neurons: involvement of both D1- and D2-like receptors. Synapse 35:111-119.

Stone EA, Zhang Y (1995) Adrenoceptor antagonists block c-fos response to stress in the mouse brain. Brain Res 694:279-286.

Tong ZY, Overton PG, Clark D (1996) Stimulation of the prefrontal cortex in the rat induces patterns of activity in midbrain dopaminergic neurons which resemble natural burst events. Synapse 22:195-208.

Van Tol HH, Bunzow JR, Guan HC, Sunahara RK, Seeman P, Niznik HB, Civelli O (1991) Cloning of the gene for a human dopamine D4 receptor with high affinity for the antipsychotic clozapine. Nature 350:610-614.

White FJ, Wang RY (1984) Electrophysiological evidence for A10 dopamine autoreceptor subsensitivity following chronic D-amphetamine treatment. Brain Res 309:283-292.

Wolf ME, White FJ, Nassar R, Brooderson RJ, Khansa MR (1993) Differential development of autoreceptor subsensitivity and enhanced dopamine release during amphetamine sensitization. J Pharmacol Exp Ther 264:249-255.

Zhang X-X, Pun C-L, Bunney BS, Shi W-X (1999) Adrenergic a1mediated increase in bursting of DA neurons: role of glutamate. Soc Neurosci Abstr 25:1819. 